\title{
FAKTOR-FAKTOR YANG MEMENGARUHI PENINGKATAN DAYA SAING KLASTER MEBEL DI KABUPATEN JEPARA
}

\author{
NANIEK UTAMI HANDAYANI ${ }^{1}$, HARYO SANTOSO ${ }^{2}$, DAN ADITHYA ICHWAL PRATAMA ${ }^{3}$ \\ Program Studi Teknik Industri, Fakultas Teknik, Universitas Diponegoro \\ E-mail: naniekh@yahoo.com
}

\begin{abstract}
ABSTRAK
Indonesia dikenal sebagai salah satu negara eksportir mebel terbesar di dunia. Namun, perkembangan ekspor mebel Jawa Tengah selama empat tahun berfluktuasi tetapi cenderung menurun, akibat krisis perekonomian dunia. Klaster industri merupakan salah satu pendekatan yang dapat digunakan untuk pengembangan industri berbasis daerah. Tujuan dari penelitian ini adalah untuk menganalisis faktor-faktor yang memengaruhi daya saing industri mebel agar dapat diambil kebijakan yang dapat digunakan untuk meningkatkan daya saing industri mebel Indonesia khususnya Jawa Tengah di pasar luar negeri. Penelitian ini menggunakan PLS (Partial Least Square) sebagai tools untuk menguji model diamond porter ditambah variabel modal sosial dan menganalisa faktor-faktor yang memengaruhi daya saing, karena jumlah ukuran populasi yang digunakan pada penelitian ini kecil. Hasil penelitian menunjukkan bahwa faktor-faktor yang memengaruhi daya saing di klaster Mulyoharjo adalah faktor kondisi, kondisi permintaan, industri pendukung dan terkait, serta strategi perusahaan. Sedangkan untuk klaster Senenan adalah faktor kondisi, peran pemerintah, kesempatan dan modal sosial.
\end{abstract}

Kata kunci: daya saing, diamond porter, partial least square

\begin{abstract}
Indonesia is known as one of the nation's largest mebel exporter in the world. But, the development of Central Java mebel exports for four years fluctuated but tended to decline that was caused by economic crisis of the world. Industrial clusters are one of the strategic that was used to develop industry based on region. The purpose of this study was to analyze the factors affecting the competitiveness of the mebel industry in order to take policies that can be used to improve the competitiveness of Indonesian mebel industry of Central Java especially in overseas markets. This study use PLS (Partial Least Square) as tools that serve to test the diamond model porter plus social capital variables and analyze the factors that affect competitiveness, caused total population size used in this study is small. The results showed that competitiveness in the Mulyoharjo furniture cluster is influenced by condition factors, demand condition, related supporting industries. Whereas, Senenan furniture cluster is influenced by condition factors, the role of government, the opportunities, and social capital.
\end{abstract}

Key words: competitiveness, diamond porter, partial least square

\section{PENDAHULUAN}

Indonesia dikenal sebagai salah satu negara eksportir mebel terbesar di dunia. Pada awal tahun 2000, Indonesia berada pada peringkat lima belas eksportir mebel dunia. Berdasarkan data Badan Pusat Statistik (BPS) dan Kamar Dagang dan Industri Indonesia (2008), pada tahun 2006 posisi ekspor produk mebel Indonesia berada pada peringkat 8 dunia di bawah Cina, Kanada, Meksiko, Itali, Vietnam, Malaysia, dan Taiwan. Jawa Tengah merupakan propinsi dengan pangsa pasar mebel sebesar 31-35\% terhadap total ekspor nasional yang menjadikan Jawa Tengah sebagai produsen mebel terbesar di Indonesia (Senada, 2007). Kabupaten Jepara merupakan produsen mebel terbesar di Jawa Tengah. Namun, data ekspor produk mebel
Jepara menunjukkan angka yang fluktuatif setiap tahunnya, dengan trend yang cenderung menurun. Hal ini diakibatkan mahalnya harga bahan baku kayu dan rendahnya mutu bahan baku yang diakibatkan pengusaha kecil dan menengah mengalami kesulitan akses terhadap bahan baku dengan harga dan kualitas terbaik. Kondisi ini mengakibatkan rendahnya daya saing pengusaha kecil dan menengah di klaster-klaster industri di Kabupaten Jepara, sehingga dapat disimpulkan bahwa produk mebel Jepara mengalami penurunan daya saing. Untuk itu, perlu dilakukan upaya-upaya yang mampu mendorong peningkatan daya saing produk-produk mebel di Kabupaten Jepara. Klaster industri merupakan salah satu pendekatan yang dapat digunakan sebagai strategi pengembangan 
industri berbasis wilayah. Pada penelitian ini, pendekatan klaster industri digunakan untuk menganalisis daya saing klaster-klaster industri penghasil mebel di Kabupaten Jepara.

Studi kasus dilakukan pada dua klaster industri di Kabupaten Jepara yaitu klaster patung di Mulyoharjo dan klaster relief di Senenan. Kedua klaster tersebut merupakan klaster industri kreatif karena proses produksinya menuntut untuk menggunakan kreatifitas dan telah mendapatkan campur tangan pemerintah dalam proses perkembangannya seperti bantuan peralatan, modal, subsidi, dan lain sebagainya. Sedangkan permasalahan yang dihadapi oleh kedua klaster industri tersebut adalah tidak terdapat ahli desain, persaingan tidak sehat dengan cara saling bersaing dalam menurunkan harga jual produk antar pelaku dalam klaster utamanya oleh pengrajin kecil, proses produksi sangat bergantung pada jumlah permintaan, desain dan standar buyer sehingga tidak terdapat stok produksi, kurangnya tenaga trampil, tenaga kerja rata-rata berpendidikan rendah dan sulit untuk diajak bekerja sama (mengikuti pelatihan, dan lain-lain), rendahnya modal yang dimiliki pengrajin, dan rendahnya kemampuan pemasaran. Faktor-faktor tersebut di atas menyebabkan rendahnya daya saing

Penelitian ini akan menganalisa hubungan antara faktor kondisi, kondisi permintaan, industri pendukung dan terkait, strategi perusahaan dan persaingan, peran pemerintah, kesempatan dan modal sosial terhadap daya saing mebel di Kabupaten Jepara yaitu di Klaster Mulyoharjo dan Senenan.

\section{METODE}

Menurut Porter $(1990,1998)$, klaster merupakan konsentrasi geografis perusahaan dan institusi yang saling berhubungan pada sektor tertentu, yang saling berhubungan karena kebersamaan dan saling melengkapi. Klaster mendorong industri untuk bersaing satu sama lain. Selain industri, di dalam klaster juga terdapat aktor lainnya seperti pemerintah dan industri yang memberikan dukungan pelayanan seperti pelatihan, pendidikan, informasi, penelitian dan dukungan teknologi. Sedangkan menurut Schmitz \& Musyck (1994) klaster didefinisikan sebagai kelompok perusahaan yang berkumpul pada satu lokasi dan bekerja pada sektor yang sama. Enright (1996, 1998, 2000) mendefinisikan klaster sebagai perusahaan-perusahaan yang sejenis/sama atau yang saling berkaitan, berkumpul dalam suatu batasan geografis tertentu. Klaster (JICA, 2004) didefinisikan sebagai pemusatan geografis industriindustri terkait dan kelembagaan-kelembagaannya.

Kementerian Koperasi dan UKM seperti tersurat dalam buku Pemberdayaan UKM
Melalui Pemberdayaan SDM dan Klaster Bisnis, menunjukkan pengertian klaster sebagai kelompok kegiatan yang terdiri atas industri inti, industri terkait, industri penunjang, dan kegiatan-kegiatan ekonomi (sektor-sektor) penunjang dan terkait lain, yang dalam kegiatannya akan saling terkait dan saling mendukung. Menurut Kuncoro (2002, 2003, 2005) klaster industri diasosiasikan dengan Marshallian Industrial District, yaitu klaster produksi yang berdekatan. Marshall (1920), menekankan pentingnya tiga jenis penghematan eksternal yang memunculkan sentra industri: (1) Konsentrasi pekerja trampil, (2) berdekatannya para pemasok spesialis, dan (3) tersedianya fasilitas untuk mendapatkan pengetahuan. Feser (2004) mendefinisikan sentra industri sebagai wilayah sosial yang ditandai dengan adanya komunitas manusia dan perusahaan, dan keduanya cenderung bersatu. Studi empiris membuktikan bahwa sentra-sentra industri dalam praktek di berbagai negara dapat digolongkan menurut: (1) struktur kelembagaan, (2) tingkat kepemilikan, (3) siklus hidup klaster.

Berdasarkan, penelitian-penelitian sebelumnya dapat disimpulkan bahwa klaster industri merupakan salah satu pendekatan atau strategi yang dapat digunakan dalam peningkatan daya saing industri. Oleh karena itu, dalam penelitian ini pendekatan klaster industri digunakan dalam menganalisis daya saing klaster industri mebel di Jepara khususnya Klaster Mulyoharjo dan Klaster Senenan.

Penelitian ini menganalisis daya saing klaster industri mebel Jepara dari sisi pengusaha yang merupakan pelaku utama dalam menjalankan proses bisnis. Model acuan yang digunakan pada penelitian ini adalah model daya saing klaster industri yang mengadopsi model diamond (Porter, 1990) yaitu faktor kondisi, kondisi permintaan, industri pendukung dan terkait, strategi perusahaan dan persaingan, peran pemerintah, dan kesempatan dengan menambahkan variabel modal sosial (Kotler 1997), yang dikembangkan menjadi model konseptual seperti disajikan pada Gambar 1.

Dimensi-dimensi tersebut digunakan untuk mengukur daya saing klaster industri. Berdasarkan dimensi-dimensi utama pada model konseptual tersebut dikembangkan model operasional yang disajikan pada Gambar 2. Dimensi faktor kondisi dibangun oleh elemen sumber daya manusia, sumber daya alam (raw material), dan pemodalan. Dimensi kondisi permintaan dibangun oleh elemen sumber permintaan, jumlah permintaan, pemasaran produk, kualitas produk, desain produk, dan variasi produk. Dimensi industri pendukung dan terkait dibangun oleh elemen letak geografis, proses pengadaan, kualitas bahan pendukung, pelatihan pemakaian 
bahan pendukung. Dimensi strategi perusahaan dan persaingan dibangun oleh elemen produk baru, penurunan harga produk dan biaya produksi, dan teknologi baru. Dimensi peran pemerintah dibangun oleh elemen program fasilitasi, pelatihan, dan kebijakan. Dimensi kesempatan dibangun oleh elemen alat teknologi dan kondisi politik. Dimensi modal sosial dibangun oleh elemen komunikasi dan interaksi, kekeluargaan, kejujuran, kerja sama, dan peraturan. Sedangkan ukuran daya saing yang digunakan adalah nilai ekspor dan volume ekspor.

Berdasarkan model konseptual tersebut maka dapat disusun hipotesis penelitian sebagai berikut: Hipotesis 1: faktor kondisi memengaruhi daya saing klaster industri
Hipotesis 2: kondisi permintaan memberikan pengaruh terhadap daya saing klaster industri

Hipotesis 3: industri pendukung dan terkait memengaruhi daya saing klaster industri

Hipotesis 4: strategi perusahaan dan pesaing memengaruhi daya saing klaster industri

Hipotesis 5: peran pemerintah berpengaruh terhadap daya saing klaster industri

Hipotesis 6: kesempatan berpengaruh terhadap daya saing klaster industri

Hipotesis 7: modal Sosial berpengaruh terhadap daya saing klaster

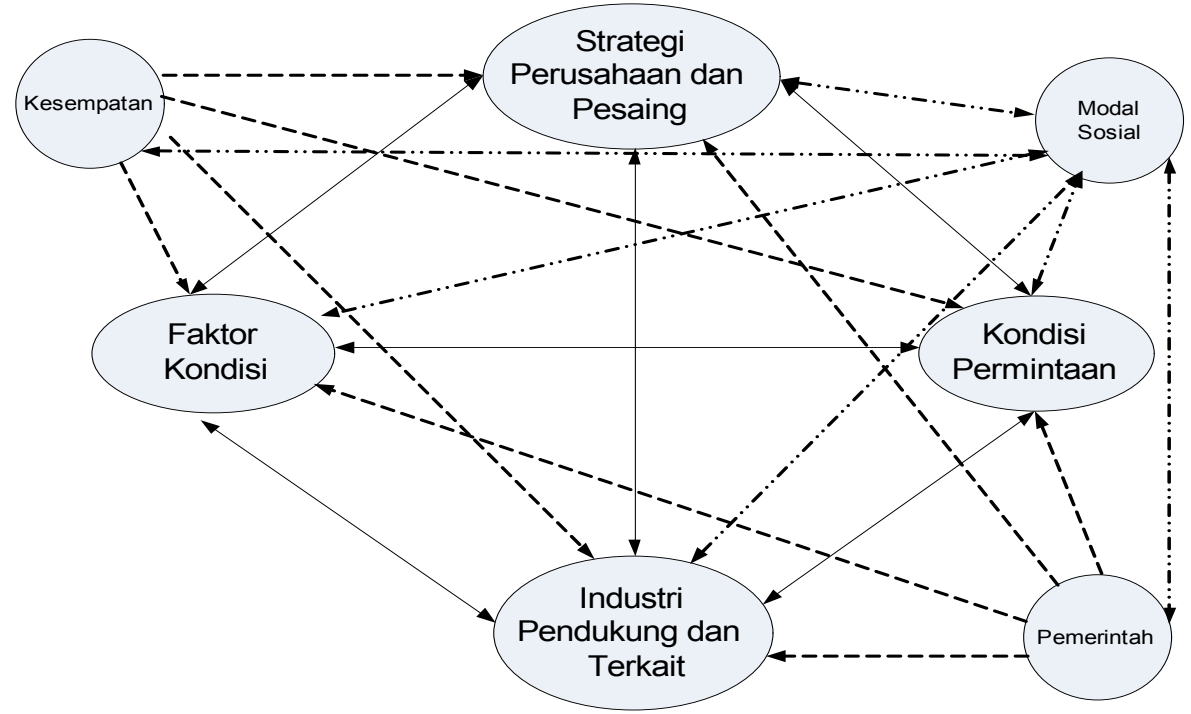

Gambar 1. Model Konseptual Dikembangkan dari Model Diamod Porter, (1990) dan Kotler, (1997)

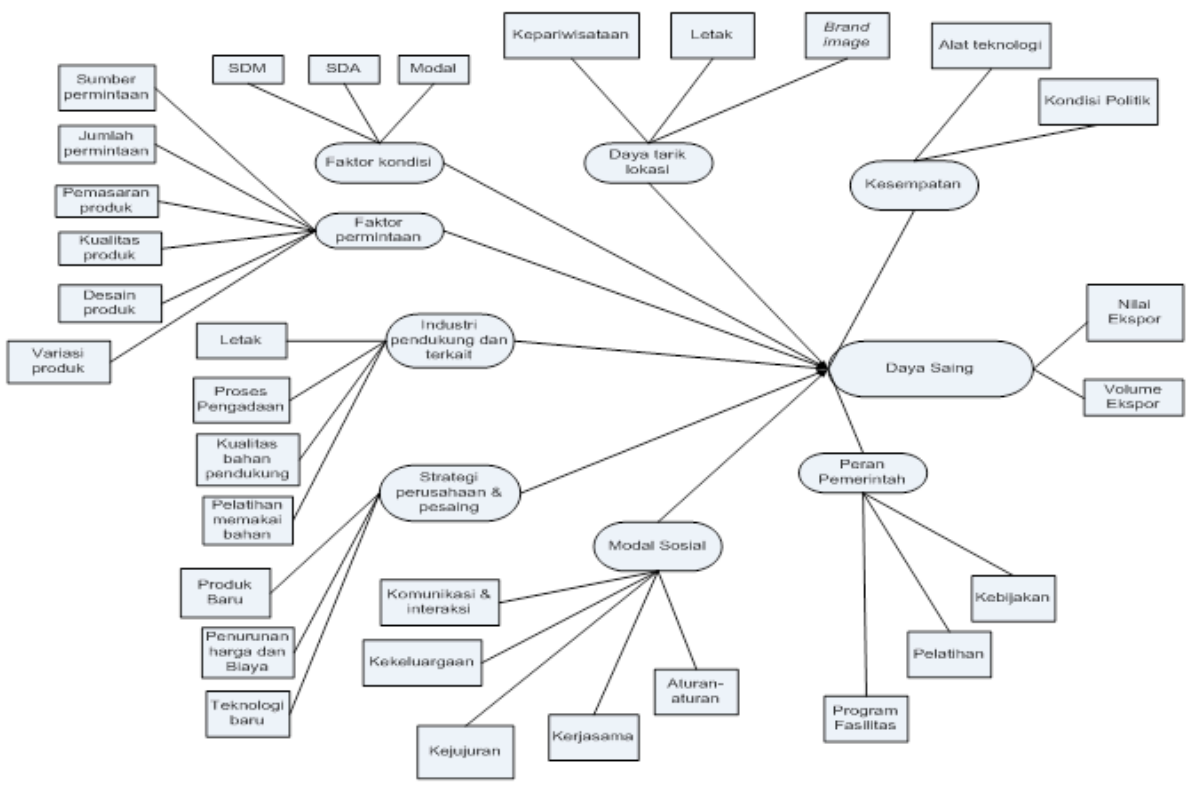

Gambar 2. Model Operasional Penelitian 
Data sekunder yang dibutuhkan pada penelitian ini adalah data ekspor mebel di Jawa Tengah, data ekspor mebel di Jepara, data pengrajin pada klaster, dan data stakeholders dalam klaster. Sedangkan, pada pengumpulan data primer dilakukan dengan beberapa metode, yaitu: 1) Wawancara, yaitu melakukan wawancara dengan pihak industri mebel dan pihak terkait untuk memperoleh informasi yang dibutuhkan, 2) Observasi, yaitu melakukan pengumpulan data secara langsung di lapangan untuk beberapa waktu, 3) Kuesioner, yaitu penyusunan pertanyaan-pertanyaan yang disebarkan kepada responden yang berhubungan dengan penelitian. Gabungan beberapa metode ini diharapkan mampu mengurangi bias, selain itu, juga digunakan sebagai proses verifikasi terhadap data yang didapatkan. Responden dalam penelitian ini adalah pengusaha kecil dan menengah pada klaster-klaster industri di Senenan dan Mulyoharjo Kabupaten Jepara dengan jumlah sampel 30 pelaku usaha untuk tiap-tiap klaster industri.

Metode pengolahan data yang digunakan pada penelitian ini adalah metode Partial Least Square (PLS) melalui pendekatan first order menggunakan software SmartPLS 2.0. PLS adalah teknik analisis multivariabel yang dapat digunakan untuk mendeskripsikan keterkaitan hubungan linear secara simultan variabel-variabel pengamatan, yang sekaligus melibatkan variabel laten yang tidak dapat diukur secara langsung. Teknik analisis data PLS dengan pendekatan first order dilakukan untuk menjelaskan secara menyeluruh hubungan antar variabel yang ada dalam penelitian di mana dalam variabel terdiri dari multidimensi. Adapun tahapan analisis dengan menggunakan metode ini adalah: 1) Analisis path diagram untuk menginterpretasikan output software PLS, 2) Analisis model pengukuran (outer model atau disebut juga measurement model) untuk mengevaluasi hubungan antara variabel konstruk dengan indikator atau variabel manifesnya, 3) Analisis struktural (inner model) untuk mengevaluasi hasil estimasi parameter path coefficiency dan tingkat signifikansinya.

\section{HASIL DAN PEMBAHASAN}

Analisis Path Diagram merupakan interpretasi hasil output software PLS yang digambarkan dalam bentuk model penelitian. Sifat indikator yang digunakan untuk mengukur variabel laten adalah refleksif. Artinya variabel laten dijelaskan oleh indikator-indikator yang menjelaskannya. Dalam path diagram model daya saing klaster mebel di Jepara, seperti yang ada pada Gambar 3, tampak bahwa terdapat 8 variabel laten. Tujuh variabel laten merupakan variabel laten eksogen dan satu buah variabel laten endogen. Variabel laten eksogen diberi nama faktor kondisi, kondisi permintaan, industri pendukung dan terkait, strategi perusahaan dan persaingan, peran pemerintah, kesempatan, dan modal sosial karena bersifat memengaruhi varibel laten lain dan tidak dipengaruhi oleh varibel laten manapun. Variabel laten endogen adalah daya saing klaster industri.

Gambar 3 memperlihatkan indikator reflektif yang merefleksikan tiap variabel laten. Faktor kondisi merefleksikan sepuluh indikator, kondisi permintaan merefleksikan tujuh indikator, industri pendukung dan terkait merefleksikan empat indikator, strategi perusahaan dan persaingan merefleksikan tiga indikator, peran pemerintah merefleksikan tiga indikator, kesempatan merefleksikan dua indikator, modal sosial merefleksikan tujuh indikator dan daya saing merefleksikan dua indikator.

Outer model atau disebut juga measurement model merupakan model yang menspesifikasi hubungan antara variabel konstruk dengan indikator atau variabel manifesnya. Penelitian ini menggunakan model Second Order Factor Analysis yang dilakukan dengan pendekatan repeated indicators, sehingga analisis outer model dilakukan pada first order construct dan second order construct. Pengujian outer model antara lain adalah uji unidimensionalitas konstruk, uji validitas dan reliabilitas indikator manifes terhadap variable konstruknya. Pengujian dilakukan dengan menggunakan software SmartPLS.

Analisis hubungan indikator terhadap first order construct dapat dijelaskan melalui convergent validity, discriminant validity dan composite reliability. Adapun output hasil PLS untuk masing-masing klaster disajikan pada Gambar 4 dan Gambar 5. Convergent validity adalah besarnya faktor loading untuk masing-masing indikator konstruk. Menurut Ghozali (2008) nilai loading harus di atas 0,70 (pada penelitian pada bidang yang belum berkembang bisa menggunakan 0,5-0,6). Dalam penelitian, peneliti menggunakan nilai faktor loading harus $\geq 0,5$, dalam arti jika terdapat nilai faktor loading kurang dari 0,5 indikator akan dihilangkan dari konstruknya.

Menurut Ghozali (2008) dan Ghozali dan Fuad (2006), sebelum melakukan eliminasi indikator, diperiksa terlebih dahulu adanya indikator yang memiliki nilai faktor loading yang negatif karena nilai faktor loading tidak boleh negatif. Untuk mengatasi hal ini maka item pertanyaan yang memiliki nilai faktor loading negatif di-recode yaitu dengan membalik skor jawaban. Setelah nilai indikator tersebut di-recode, indikator tersebut diolah kembali dengan menggunakan software SmartPLS. 


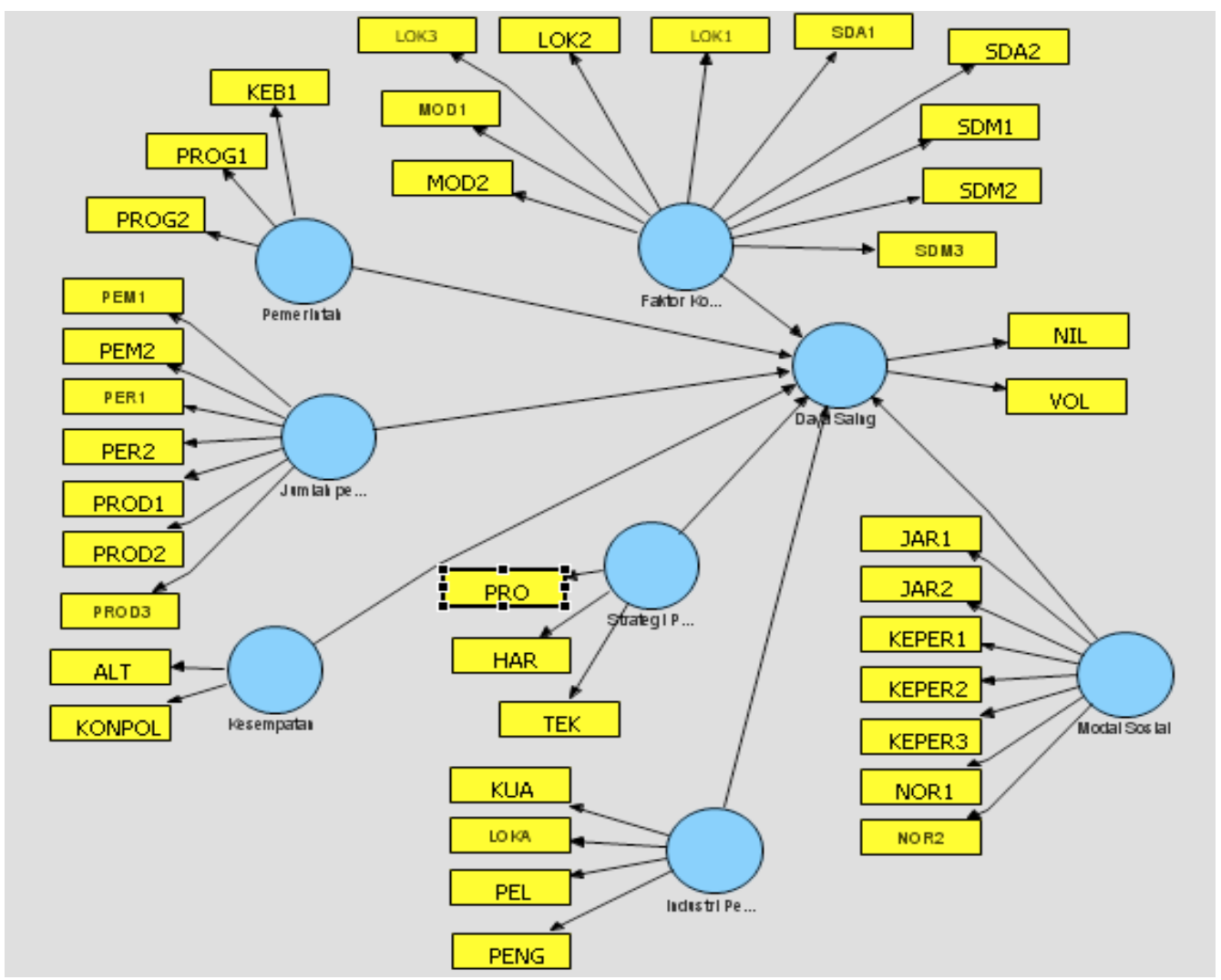

Gambar 3. Path Diagram Klaster Mebel Ukir Jepara

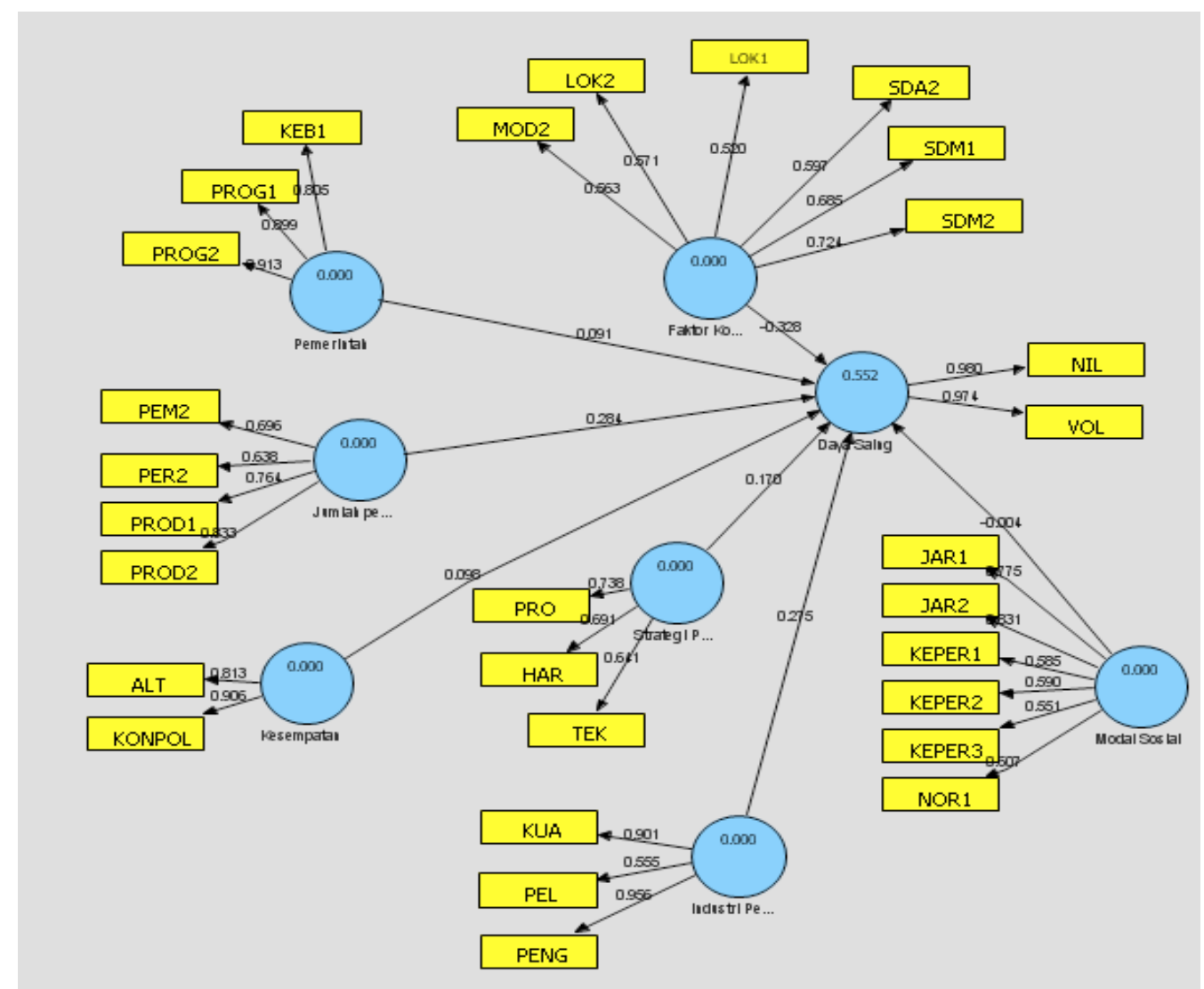

Gambar 4. Hasil Output PLS Klaster Mulyoharjo setelah Memenuhi Convergent Validity 


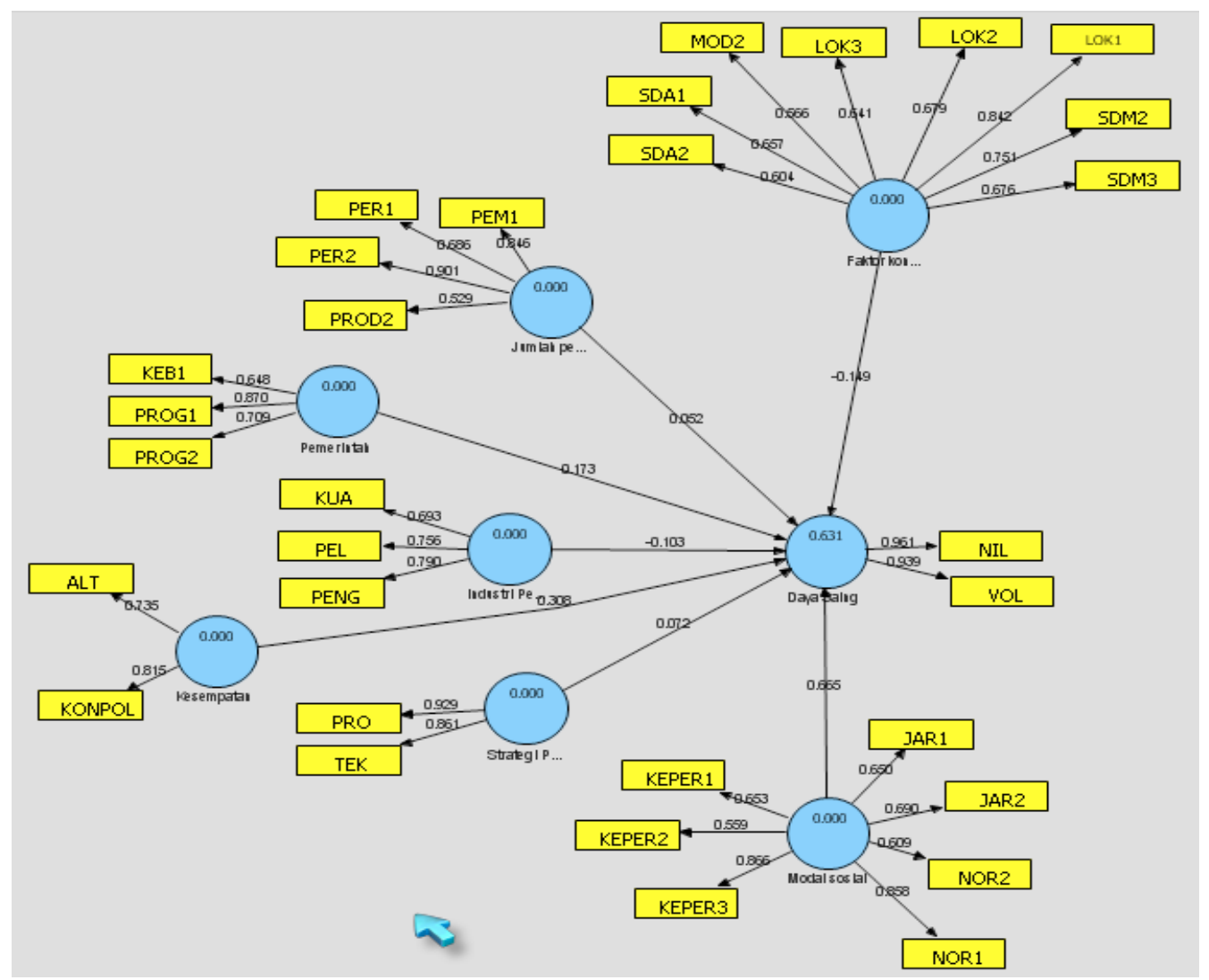

Gambar 5. Hasil Output PLS Klaster Senenan setelah Memenuhi Convergent Validity

Selanjutnya dilakukan uji validitas indikator terhadap first order construct untuk menjelaskan besarnya dukungan tiap-tiap indikator.

Berdasarkan hasil uji validitas indikator tersebut dapat disimpulkan indikator-indikator yang memberikan pengaruh terbesar terhadap masingmasing first order constructs untuk masing-masing klaster. Indikator-indikator yang memberikan pengaruh terbesar untuk tiap tiap first order construct pada klaster Mulyoharjo dan klaster Senenan disajikan pada Tabel 1.
Pengukuran discriminant validity pada penelitian ini adalah dengan membandingkan nilai Average Variance Extracted (AVE) dengan nilai akar AVE. Nilai akar AVE haruslah lebih besar dari nilai AVE untuk dapat memenuhi kriteria discriminant validity. Dari hasil perhitungan diperoleh akar AVE konstruk industri pendukung dan terkait sebesar 0,822 lebih tinggi daripada korelasi antara konstruk Industri Pendukung dan Terkait dengan Daya Saing yang hanya sebesar 0,319 untuk klaster Mulyoharjo dan untuk klaster Senenan, akar AVE

Tabel 1. Indikator yang Memberikan Pengaruh Terbesar terhadap Masing-masing First Order Constructs pada Tiaptiap Klaster

\begin{tabular}{|c|c|c|c|}
\hline \multirow{2}{*}{ No } & \multirow{2}{*}{ First Order Construct } & \multicolumn{2}{|c|}{ Indikator } \\
\hline & & Klaster Mulyoharjo & Klaster Senenan \\
\hline 1 & Faktor kondisi & Keahlian SDM & Brand image \\
\hline 2 & Kondisi permintaan & Desain produk & Jumlah permintaan \\
\hline 3 & Industri pendukung dan terkait & Pengadaan bahan pendukung & Pengadaan bahan pendukung \\
\hline 4 & Strategi perusahaan dan persaingan & Keberadaan produk baru & Strategi produk baru \\
\hline 5 & Peran Pemerintah & $\begin{array}{l}\text { Pelatihan yang dilakukan oleh } \\
\text { pemerintah (dinas terkait) }\end{array}$ & $\begin{array}{l}\text { Program pemerintah yang } \\
\text { memfasilitasi pengusaha dalam klaster }\end{array}$ \\
\hline 6 & Kesempatan & Kondisi politik di kabupaten Jepara & Kondisi politik di kabupaten Jepara \\
\hline 7 & Modal sosial & Interaksi antar pelaku dalam klaster & $\begin{array}{l}\text { Aturan yang bersifat fleksibel karena } \\
\text { adanya kepercayaan }\end{array}$ \\
\hline
\end{tabular}


konstruk Industri Pendukung dan Terkait sebesar 0,746 lebih tinggi daripada korelasi antara konstruk Industri Pendukung dan Terkait dengan Daya Saing yang hanya sebesar 0,319 , begitu juga dengan konstruk konstruk lainnya sehingga semua konstruk dalam model yang diestimasi memenuhi kriteria discriminant validity.

Composite reliability berfungsi untuk mengukur reliabilitas suatu konstruk. Pada penelitian ini composite reliability dilihat dari nilai internal consistency yang dihasilkan dalam output SmartPLS. Nilai reliabilitas yang disyaratkan bernilai 0,6 atau lebih. Nilai composite reliability dari setiap variabel laten berada di atas 0,6 sehingga dapat disimpulkan variabel-variabel tersebut reliabel.

Menilai inner model adalah mengevaluasi hasil estimasi parameter path coefficiency dan tingkat signifikansinya. Model struktural dievaluasi dengan menggunakan $\mathrm{R}$-square untuk konstruk dependen dan uji t serta signifikansi dari koefisien parameter jalur struktural. Interpretasi nilai R-square yang menunjukkan besar pengaruh hubungan.

Hasil analisis terhadap faktor-faktor yang berpengaruh terhadap daya saing pada klaster Mulyoharjo adalah sebagai berikut: Hipotesis 1 diterima, artinya konstruk faktor kondisi terbukti secara statistik memengaruhi daya saing dikarenakan nilai t statistik pada hubungan ini adalah 4,427 berada dalam area penerimaan untuk signifikansi $\alpha=0,1$ dengan $\mathrm{db}=34$. Hipotesis 2 diterima, artinya konstruk kondisi permintaan terbukti secara statistik memengaruhi daya saing terhadap daya saing. Hal ini ditunjukkan dengan nilai t statistik sebesar 4,218 berada dalam area penerimaan untuk signifikansi $\alpha=0,1$ dengan $d b=34$. Hipotesis 3 diterima, artinya, konstruk Industri Pendukung dan Terkait terbukti secara statistik memengaruhi daya saing. Nilai t statistik pada hubungan ini adalah 4,481. Nilai t statistik ini berada dalam area penerimaan, yaitu berada di luar area 1,691 untuk signifikansi $\alpha=0,1$ dengan $d b=34$. Hipotesis 4 diterima, artinya, konstruk strategi perusahaan dan persaingan terbukti secara statistik memengaruhi daya saing.Nilai t statistik pada hubungan ini adalah 1,858 . Nilai $t$ statistik ini berada dalam area penerimaan, yaitu berada di luar area 1,691 untuk signifikansi $\alpha=0,1$ dengan $d b=34$. Hipotesis 5 ditolak, artinya, konstruk peran pemerintah secara statistik tidak memengaruhi daya saing. Nilai t statistik sebesar 0,991 berada dalam area penolakan untuk signifikansi $\alpha=0,1$ dengan $d b=34$. Hipotesis 6 ditolak, artinya, konstruk kesempatan terbukti secara statistik tidak memengaruhi daya saing. Nilai t statistik sebesar 1,237 berada dalam area penolakan untuk signifikansi $\alpha=0,1$ dengan $d b=34$.
Hipotesis 7 ditolak, artinya, konstruk modal sosial terbukti secara statistik tidak memengaruhi daya saing.Nilai t statistik pada hubungan ini adalah 0,044. Nilai t statistik ini berada dalam area penolakan, yaitu berada di dalam area 1,691 untuk signifikansi $\alpha=0,1$ dengan $\mathrm{db}=34$. Dengan demikian,

Hasil analisis terhadap faktor-faktor yang berpengaruh terhadap daya saing pada klaster Senenan adalah sebagai berikut: Hipotesis 1 diterima, artinya, konstruk faktor kondisi terbukti secara statistik memengaruhi daya saing. Nilai $t$ statistik pada hubungan ini adalah 1,809. Nilai t statistik ini berada dalam area penerimaan, yaitu berada di luar area 1,699 untuk signifikansi $\alpha=0,1$ dengan $\mathrm{db}=29$. Hipotesis 2 ditolak, artinya, konstruk kondisi permintaan terbukti secara statistik tidak memengaruhi daya saing. Nilai t statistik pada hubungan ini adalah 0,753. Nilai t statistik ini berada dalam area penolakan, yaitu berada di dalam area 1,699 untuk signifikansi $\alpha=0,1$ dengan $d b=29$. Hipotesis 3 ditolak, artinya, konstruk Industri Pendukung dan Terkait terbukti secara statistik tidak memengaruhi daya saing. Nilai t statistik pada hubungan ini adalah 0,972 . Nilai $t$ statistik ini berada dalam area penolakan, yaitu berada di dalam area 1,699 untuk signifikansi $\alpha=0,1$ dengan $d b=29$. Hipotesis 4 ditolak, artinya, konstruk strategi perusahaan dan persaingan terbukti secara statistik tidak memengaruhi daya saing. Nilai t statistik pada hubungan ini adalah 0,959. Nilai t statistik ini berada dalam area penolakan, yaitu berada di dalam area 1,699 untuk signifikansi $\alpha=0,1$ dengan $d b=29$. Hipotesis 5 diterima, artinya, konstruk peran pemerintah terbukti secara statistik memengaruhi daya saing. Nilai t statistik pada hubungan ini adalah 2,848 dan berada pada area penerimaan. Hipotesis 6 diterima, artinya, konstruk kesempatan terbukti secara statistik memengaruhi daya saing. Nilai t statistik pada hubungan ini adalah 3,819. Nilai t statistik ini berada dalam area penerimaan, yaitu berada di luar area 1,699 untuk signifikansi $\alpha=0,1$ dengan $d b=29$. Hipotesis 7 diterima, artinya, konstruk modal sosial terbukti secara statistik memengaruhi daya saing.Nilai $t$ statistik pada hubungan ini adalah 7,550. Nilai t statistik ini berada dalam area penerimaan, yaitu berada di luar area 1,699 untuk signifikansi $\alpha=0,1$ dengan $d b=29$. Berdasarkan uraian di atas dapat disimpulkan hasil pengujian hipotesis seperti disajikan pada Tabel 2.

Selanjutnya, secara umum untuk kedua klaster tersebut dapat disusun rekomendasi perbaikan. Rekomendasi perbaikan pada dasarnya disusun berdasarkan faktor-faktor yang masih memiliki nilai rendah, baik pada kondisi hipotesis ditolak 
maupun pada hipotesis diterima. Rekomendasi tersebut, yaitu: a) meningkatkan kapasitas sumber daya manusia yang masih kurang dengan melakukan pelatihan-pelatihan yang sesuai dan berkelanjutan dari pemerintah, sehingga pelatihan yang dilakukan pemerintah tepat sasaran dan dapat meningkatkan daya saing UKM mebel, b) perlunya sebuah inovasi produk dengan desain-desain baru yang dapat menangkap keinginan pasar dengan mengadakan penelitian pasar, c) mengoptimalkan promosi produk-produk mebel melalui pameran dan internet, d) perlunya program pelatihan dan penyuluhan yang berkelanjutan dan di program untuk jangka waktu tertentu, e) menetapkan standar harga untuk produk-produk mebel agar tidak terjadi persaingan harga yang kurang sehat antar pelaku usaha.

\section{SIMPULAN}

Berdasarkan analisis yang telah dilakukan didapat kesimpulan mengenai faktor-faktor yang berpengaruh terhadap daya saing pada masingmasing klaster. Untuk klaster Mulyoharjo, faktorfaktor yang memengaruhi daya saing adalah faktor kondisi, kondisi permintaan, industri pendukung dan terkait, serta strategi perusahaan. Sedangkan untuk klaster Senenan, faktor-faktor yang memengaruhi daya saing adalah faktor kondisi, peran pemerintah, kesempatan dan modal sosial. Penelitian selanjutnya adalah membangun model pola pertumbuhan klaster industri mebel khususnya di Jawa Tengah.

\section{APENDIKS}

Tabel 2. Hasil Pengujian Hipotesis

\begin{tabular}{llcc}
\hline & \multicolumn{1}{c}{ Hubungan } & Mulyoharjo & Senenan \\
\hline H1 & $\begin{array}{l}\text { Faktor kondisi } \\
\text { berpengaruh terhadap } \\
\text { daya Saing klaster industri }\end{array}$ & Diterima & Diterima \\
\hline H2 & $\begin{array}{l}\text { Industri pendukung dan } \\
\text { terkait berpengaruh } \\
\text { terhadap daya Saing } \\
\text { klaster industri }\end{array}$ & Diterima & Ditolak \\
\hline H3 & $\begin{array}{l}\text { Kondisi permintaan } \\
\text { berpengaruh terhadap } \\
\text { daya Saing klaster industri }\end{array}$ & Diterima & Ditolak \\
\hline H4 & $\begin{array}{l}\text { Strategi perusahaan } \\
\text { berpengaruh terhadap } \\
\text { daya Saing klaster industri }\end{array}$ & Diterima & Ditolak \\
\hline H5 & $\begin{array}{l}\text { Pemerintah berpengaruh } \\
\text { terhadap daya Saing } \\
\text { klaster industri }\end{array}$ & Ditolak & Diterima \\
\hline H6 & $\begin{array}{l}\text { Kesempatan berpengaruh } \\
\text { terhadap daya Saing } \\
\text { klaster industri }\end{array}$ & Ditolak & Diterima \\
\hline H7 & $\begin{array}{l}\text { Modal Sosial berpengaruh } \\
\text { terhadap daya Saing } \\
\text { klaster industri }\end{array}$ & Ditolak & Diterima \\
\hline & & & \\
\hline
\end{tabular}

\begin{tabular}{|c|c|}
\hline SDM1 & : Asal SDM \\
\hline SDM2 & : Keahlian SDM \\
\hline SDM3 & : Kualitas SDM \\
\hline SDA1 & : Kualitas bahan baku \\
\hline SDA2 & : Asal bahan baku \\
\hline MOD1 & : Ketersediaan modal \\
\hline MOD2 & : Asal Modal \\
\hline LOK1 & : Letak Geografis \\
\hline LOK2 & : Kepariwisataan \\
\hline LOK3 & : Brand Image \\
\hline PER1 & : Sumber permintaan \\
\hline PER2 & : Jumlah permintaan \\
\hline PEM1 & : Permintaan Langsung \\
\hline PEM2 & : Permintaan Tidak langsung \\
\hline PROD1 & : Kualitas produk \\
\hline PROD2 & : Desain produk \\
\hline PROD3 & : Variasi produk \\
\hline LOKA & : Letak industri pendukung \\
\hline PENG & : Proses pengadaan bahan pendukung \\
\hline KUA & : Kualitas bahan pendukung \\
\hline PEL & : Pelatihan memakai bahan pendukung \\
\hline PRO & : Produk baru \\
\hline HAR & : Harga \\
\hline TEK & : Teknologi \\
\hline PROG1 & : Program fasilitasi \\
\hline PROG2 & : Pelatihan \\
\hline KEB1 & : Kebijakan industri kecil \\
\hline ALT & : Alat untuk proses produksi \\
\hline \multicolumn{2}{|c|}{ KONPOL: Kondisi yang terjadi } \\
\hline \multicolumn{2}{|c|}{ KEPER1 : Kejujuran } \\
\hline \multicolumn{2}{|c|}{ KEPER2 : Kerja sama } \\
\hline \multicolumn{2}{|c|}{ KEPER3 : Aturan-aturan } \\
\hline NOR1 & : Kekeluargaan \\
\hline NOR2 & : Norma Sosial \\
\hline JAR1 & : Komunikasi \\
\hline JAR2 & : Interaksi \\
\hline
\end{tabular}

\section{DAFTAR PUSTAKA}

BPS, 2007. Statistik Perdagangan Luar.

Enright, M., 1996. Regional clusters and firm strategy, in Business Networks: Prospects for Regional Development, Eds. U. Staber, N. Schaefer \& B. Sharma, de Gruyter, Berlin and New York, pp. 190213.

Enright, M., 1998. Regional clusters and firm strategy, in The Dynamic Firm: The Role of Technology, Strategy, Organisation, and Regions, Eds. J. Chandler, A.D.. Ö Sölvell \& P. Hagström, Oxford University Press, Oxford.

Enright, M., 2000. The globalisation of competition and the localisation of competitive advantage: Policies towards regional clustering, in The Globalisation of Multinational Enterprise Activity and Economic 
Development, Eds. N. Hood \& S. Young, McMillian Press, Basingstoke pp. 303-31.

Feser, E., 2004. Industry Clusters and Economic Development: A Learning Resource, Community and Economic Development Toolbox.

Ghozali, Imam dan Fuad, 2006. Structural Equation Modeling, Teori Konsep dan aplikasi. Badan Penerbit Universitas Diponegoro, Semarang.

Ghozali, Imam, 2008. Structural Equation Modeling, Metode Alternatif dengan Partial Least Square (PLS), Badan Penerbit Universitas Diponegoro, Semarang.

JICA, 2004. Studi Penguatan Kapasitas Klaster UKM di Republik Indonesia.

Kadin, 2007. Visi 2030 \& Roadmap 2010 Industri Nasional, Jakarta, Kadin Indonesia.

Kotler, P., Jatusripitak, S., and Maesincee, S., 1997. The Marketing of Nations, A strategic Approach to Building National Wealth, The Free Press, New York.

Kuncoro, M., 2002. Adakah perubahan konklastersi spasial industri manufaktur di indonesia, 1976-2001?
Jurnal Ekonomi dan Bisnis Indonesia. Yogyakarta: Fakultas Ekonomi UGM.

Kuncoro, M. dan Supomo, I.A., 2003. Analisis formasi keterkaitan, pola klaster dan orientasi pasar: studi kasus klaster industri keramik di kasongan, kabupaten bantul, di Yogyakarta. Yogyakarta: Jurnal Empirika,

Kuncoro, M., 2005. Aglomerasi perkotaan di DIY: Apa, di mana, dan mengapa? Yogyakarta. Fakultas Ekonomi UGM.

Marshall, A., 1920. Principles of Economics, MacMillan and Co Ltd., $8^{\text {th }}$ edition, London.

Porter, M., 1990. The Competitive Advantage of Nations, New York.

Porter, M.E., 1998. On Competition. Boston: Harvard Business School Publishing.

Schmitz, H. and Musyck, B., 1994. Industrial Districts in Europe: Policy Lessons for Developing Countries?, World Development, 22 (6), 889-910.

Senada, 2007. Studi Hambatan Kebijakan Bagi Industri Furnitur. Hasil Studi di Jawa Timur dan Jawa Tengah. 